(Received June 22, 1981)

\title{
ANTICOAGULANT ACTIVITY OF SODIUM AMINODEOXYCELLULOSE SULFATES
}

\author{
By Takuma Teshirogi ${ }^{* 1}$, Hideo Kusaoke ${ }^{* 2, * 4}$, \\ Munenori Sakamoto ${ }^{* 2}$ and Hiroaki Tonami ${ }^{* 3}$ \\ *1 (Yamagata University, Yonezawa, Yamagata) \\ *2 (Tokyo Institute of Technology, Meguroku, Tokyo) \\ *3 (Japan Women's University, Bunkyoku, Tokyo)
}

\begin{abstract}
Synopsis
The anticoagulant activity of sodium aminopolysaccharide sulfates was tested in vitro by Lee and White method. All of them showed an activity in delaying coagulation of blood. Several sodium aminodeoxycellulose sulfates had higher anticoagulant activity than all of the commercial anticoagulants except for sodium heparinate.

Some films prepared by treating sodium aminodeoxycellulose sulfates with formalin or polyvinyl alcohol also had an anticoagulant activity.
\end{abstract}

\section{INTRODUCTION}

The most familiar property of heparin is a high activity as blood-anticoagulant, and is important for medical purposes ${ }^{1-5)}$. Mechanism of coagulation of blood is the conversion of soluble fibrinogen in blood into insoluble fibrin. This conversion is controlled by thrombin which is formed from prothrombin by catalysis with thrombokinase ${ }^{6}$. Several works ${ }^{7-10}$ ) on the syntheses of heparin analogue-polysaccharides (Heparinoid) have been reported. Whistler et al. ${ }^{11}$ ) have stated that sodium salts of $\mathrm{N}$ - and $\mathrm{O}$-sulfated chitosan and selectively $\mathrm{N}$-sulfated chitosan were prepared and found to possess the high anticoagulant activity. Sodium aminodeoxycellulose sulfates obtained in a previous paper ${ }^{12)}$ show the structural similarity to heparin and are expected to possess the anticoagulant activity.

Recently with the progress of medical science, many polymeric materials have become to be used for diagnosis and medical treatments ${ }^{13-15}$. The antithrombogenic materials have been developed for artificial organs. For example, Tanzawa et al. ${ }^{16)}$ reported that the hydrophilic polyethylene glycol methacrylate and the quarternary ammonium salt of dimethylaminoethyl methacrylate were grafted

\footnotetext{
${ }^{\circ 4}$ Present address; Nikka Kagaku Co., Fukui, Fukui
}

on the copolymer of vinyl chloride/vinyl acetate and the anticoagulant material was obtained by treatment of this graft copolymer with heparin. Sasaki ${ }^{17)}$ reported that the insoluble antithrombogenic films were prepared by treatment of various anticoagulants with formalin or polyvinyl alcohol (PVA).

In this paper, the anticoagulant activity of sodium aminodeoxycellulose sulfates prepared in the previous paper ${ }^{12)}$ is tested in vitro and some attempts are made to correlate the structure of the sulfates with their anticoagulant activity. The activity of films obtained by treatment of the sulfates with formalin or PVA in a similar way to the method of Sasaki ${ }^{17)}$ is also tested in vitro in an attempt to develop new antithrombogenic materials from cellulose.

\section{RESULTS AND DISCUSSION}

In order to investigate the anticoagulant activity of sodium aminodeoxycellulose sulfates and sodium 6-amino-6-deoxystarch sulfate, the blood coagulation time in the presence of these compounds was measured by Lee and White method ${ }^{18)}$. Experimental results with the concentration of $5 \mathrm{mg}$ of the sulfates per $1 \mathrm{ml}$ of blood are shown in Table 1. Sodium aminodeoxycellulose sulfates obtained by sulfation of aminodeoxycellulose and successive nutralization with sodium hydroxide 
Table 1 Anticoagulant activity of sodium aminodeoxycellulose sulfates.

\begin{tabular}{lccc}
\hline Sodium Polysaccharide Sulfate & $\mathrm{DS}_{\mathrm{NH}_{2}}$ & Abbreviation & $\begin{array}{c}\text { Whale blood coagulation } \\
\text { time } \\
\left(\mathrm{min} \mathbf{m g}^{\mathrm{a}} \mathrm{m} / \mathrm{ml}^{\mathrm{b}} \text { ) }\right.\end{array}$ \\
\hline Sodium aminodeoxycellulose sulfate & 0.04 & $\mathrm{ACS}_{0.04}$ & 0 \\
Sodium aminodeoxycellulose sulfate & 0.08 & $\mathrm{ACS}_{0.08}$ & 0 \\
Sodium aminodeoxycellulose sulfate & 0.16 & $\mathrm{ACS}_{0.16}$ & 0 \\
Sodium aminodeoxycellulose sulfate & 0.68 & $\mathrm{ACS}_{0.68}$ & 0 \\
Sodium aminodeoxycellulose sulfate & 0.82 & $\mathrm{ACS}_{0.82}$ & 34.8 \\
Sodium 6-amino-6-deoxycellulose sulfate & 0.90 & 6ACS & 0 \\
Sodium 6-amino-6-deoxycellulose N-sulfate & 0.90 & 6ACS-N & 10.6 \\
Sodium 2-amino-2-deoxycellulose sulfate & 0.37 & 2ACS & 0 \\
Sodium 6-amino-6-deoxystarch sulfate & 0.92 & $6 \mathrm{ASS}$ & 0 \\
Sodium chitosan sulfate & 1.00 & & 0 \\
Sodium cellulose sulfate & & & 29.5 \\
Sodium heparinate & & & 0 \\
Control & & 5.7 \\
\hline
\end{tabular}

a) $O$; No coagulation of blood after 2.5 hr elapse.

b) Concentration: $5 \mathrm{mg}$ of anticoagulant per $1 \mathrm{ml}$ of blood.

were abbreviated to $\mathrm{ACS}_{0.04}, \mathrm{ACS}_{0.08}, \ldots$ The subscripts of $0.04,0.08, \cdots$ correspond to degree of substitution (DS) of amino group in original aminodeoxycellulose ${ }^{19)}$. The sodium sulfates prepared from 6-amino-6-deoxycellulose ${ }^{20}$ ) 2 -amino2-deoxycellulose ${ }^{21)}$, and 6-amino-6-deoxystarch ${ }^{22)}$ were abbreviated to 6ACS, $2 \mathrm{ACS}$, and 6ASS, respectively. Sodium salt of $\mathrm{N}$-sulfated product of 6-amino-6-deoxycellulose was abbreviated to 6ACS$\mathrm{N}$. All of these sodium sulfates were readily soluble in water expect for $\mathrm{ACS}_{0.68}$ and $\mathrm{ACS}_{\mathbf{0 . 8 2}}$.

The high anticoagulant activity was observed for $\mathrm{ACS}_{0.04}, \mathrm{ACS}_{0.08}, \mathrm{ACS}_{0.16}, \mathrm{ACS}_{0.68}, 6 \mathrm{ACS}, 2 \mathrm{ACS}$, and 6ASS. The anticoagulant activity of 6ACS-N was very low, compared with that of 6ACS. This suggests that both $\mathrm{O}$-sulfate and $\mathrm{N}$-sulfate groups are necessary for a high anticoagulant activity. This agrees with the report of Whistler et al. that sodium chitosan $\mathrm{O}$ - and $\mathrm{N}$-sulfates had a high anticoagulant activity whereas sodium chitosan $\mathrm{N}$-sulfate did not. It is interesting that $\mathrm{ACS}_{0.68}$ insoluble in water possess a high activity because of the possibility of development of solid anticoagulant materials.

The anticoagulant activity of these salts was further investigated at lower concentration (Table

Table 2 Effect of concentration of sodium aminodeoxycellulose sulfate on blood-coagulation time.

\begin{tabular}{lcc}
\hline \multirow{2}{*}{ Sodium Polysaccharide Sulfate } & \multicolumn{2}{c}{ Whole blood coagulation time $(\mathrm{min})^{\mathrm{a}}$} \\
\cline { 2 - 3 } & $0.5 \mathrm{mg} / \mathrm{ml}$ & $0.05 \mathrm{mg} / \mathrm{ml}$ \\
\hline ACS $_{0.04}$ & 0 & 9.3 \\
ACS $_{0.08}$ & 0 & 27.5 \\
ACS $_{0.16}$ & 0 & 7.5 \\
6ACS & 0 & 8.9 \\
2ACS & 36.8 & 5.4 \\
6ASS & 53.7 & 5.5 \\
Sodium chitosan sulfate & 6.5 & 3.6 \\
Sodium heparinate & 0 & \\
\hline
\end{tabular}

a) $\bigcirc$; No coagulation of blood after 1.5 -hr elapse. 
2). $\mathrm{ACS}_{0.04}, \mathrm{ACS}_{0.08}, \mathrm{ACS}_{0.16}$, and $6 \mathrm{ACS}$ showed a high activity at the concentration of $0.5 \mathrm{mg}$ of anticoagulant per $1 \mathrm{ml}$ of blood. However, 2ACS, $6 \mathrm{ASS}$, and sodium chitosan sulfate showed a low activity at this concentration.

On the other hand, complete coagulation of blood was observed in 5 to $30 \mathrm{~min}$. in the presence of lower concentration of $0.05 \mathrm{mg}$ of anticoagulant per $1 \mathrm{ml}$ of blood.

From the results described above, the following conclusions were deduced. For anticoagulation of blood, an anticoagulant has a threshold value. Moreover, ACS with low DS of sulfoamino group has as high activity as 6ACS with high DS of regioselective sulfoamino group. However, the anticoagulant activity of $6 \mathrm{ACS}$ is higher than that of $2 \mathrm{ACS}$,

Table 3 shows many kinds of commercial anticoagulants $^{23}$ ) and the contents of anticoagulant required to possess anticoagulant activity per $1 \mathrm{ml}$ of blood. Some of sodium aminodeoxycellulose sulfates investigated above have higher activities than all of the commercial anticoagulants except for sodium heparinate.

In order to determine the effect of functional group arrangement around the surface of solid anticoagulant materials, the anticoagulant activity of insoluble films which were obtained by treatment of sodium aminodeoxypolysaccharide sulfates with formalin or PVA in a similar way to the method of Sasaki ${ }^{16)}$, was tested in vitro by Lee and White method. Table 4 shows coagulation time of blood in a test tube of which inner wall was coated with the anticoagulant film. Films made from sodium sulfates (6ACS, $2 \mathrm{ACS}$, and 6ASS) of aminopolysaccharides, which were obtained by regioselective amination of polysaccharides, remarkably prohibited blood coagulation. However, blood coagulation was observed for films made from $\mathrm{ACS}_{0.04}, \mathrm{ACS}_{0.16}$, and sodium cellulose sulfate in almost equal time to that for control films. It is interesting that sodium aminodeoxycellulose sulfates which showed high anticoagulant activity in blood solution did not give films with the activity. Probably, regular orientation of $\mathrm{N}$ sulfate group at the surface of the films is a very

Table 3 Minimum contents required to possess anticogulant activity per $1 \mathrm{ml}$ of blood at various commercial anticoagulants. ${ }^{*}$

\begin{tabular}{|c|c|c|}
\hline Anticoagulant & Structural formula & $\begin{array}{l}\text { Minimum content per } \\
1 \mathrm{ml} \text { of blood }\end{array}$ \\
\hline Sodium heparinate & & $0.01 \mathrm{mg}$ \\
\hline Sodium citrate & $\begin{array}{c}\mathrm{CH}_{2} \mathrm{COONa} \\
\mathrm{HOCCOONa} \cdot 2 \mathrm{H}_{2} \mathrm{O} \\
\stackrel{\mathrm{C}}{\mathrm{CH}_{2} \mathrm{COONa}}\end{array}$ & $5 \mathrm{mg}$ \\
\hline Sodium dextran sulfate & & $5-10 \mathrm{mg}$ \\
\hline Sodium oxalate & $\begin{array}{l}\mathrm{COONa} \\
\stackrel{\mathrm{COONa}}{ }\end{array}$ & $1-2 \mathrm{mg}$ \\
\hline Potassium oxalate & $\begin{array}{l}\text { COOK } \\
1 \\
\text { COOK }\end{array}$ & $1-2 \mathrm{mg}$ \\
\hline Sodium fluoride & $\mathrm{NaF}$ & $5-10 \mathrm{mg}$ \\
\hline $\begin{array}{l}\text { Ethylenediaminetetra- } \\
\text { acetic acid (EDTA-2Na) }\end{array}$ & $\mathrm{HOOCH}_{2} \mathrm{C}^{\mathrm{NaOOCH}} \mathrm{CH}_{2}-\mathrm{CH}_{2}-\mathrm{N} / \mathrm{CH}_{2} \mathrm{COOH}$ & $1 \mathrm{mg}$ \\
\hline $\begin{array}{l}\text { ACD liquid (acid } \\
\text { citrate dextrose) }\end{array}$ & $\begin{array}{l}\text { Citric acid, Sodium citrate, dextrose, } \\
\text { and } \mathrm{H}_{2} \mathrm{O}\end{array}$ & $5 \mathrm{mg}$ \\
\hline Double oxalate & $\begin{array}{l}\text { Potassium oxalate, Ammonium oxalate, } \\
\text { and } \mathrm{H}_{2} \mathrm{O}\end{array}$ & $2 \mathrm{mg}$ \\
\hline
\end{tabular}

*; Reference 23) 
Table 4 Blood-coagulation time in a glass tube of which inner wall was coated with films prepared from $5 \%$ formalin or $2 \%$ PVA solutions containing sodium aminodeoxycellulose sulfate as anticoagulant.

\begin{tabular}{lcc}
\hline \multirow{2}{*}{ Sodium Polysaccharide Sulfate } & \multicolumn{2}{c}{ Whole blood coagulation time $\left.(\mathrm{min})^{\mathrm{a}}\right)$} \\
\cline { 2 - 3 } & $5 \%$ Formalin & 2\% Polyvinylalcohol \\
\hline ACS $_{0.04}$ & 5.0 & 26.0 \\
ACS $_{0.16}$ & 4.9 & 5.7 \\
6ACS & 0 & 0 \\
2ACS & 0 & 0 \\
6ASS & 0 & 0 \\
Sodium chitosan sulfate & 0 & 20.5 \\
Sodium cellulose sulfate & 3.8 & 30.5 \\
Sodium heparinate & $\bigcirc$ & 0 \\
Control & 2.7 & 12.3 \\
\hline
\end{tabular}

a) $O$; No coagulation of blood after 1.5-hr elapse.

important factor in exhibiting high anticoagulant properties of solid materials. Such a factor is not necessary for the properties of sodium aminodeoxycellulose sulfates in blood solution. From these results, 6ACS, 2ACS, and 6ASS may be expected useful for the development of solid anticoagulant materials.

\section{EXPERIMENTAL}

Materials and method .... The blood was obtained from the artery of dogs. Various sodium aminodeoxycellulose sulfates and 6-amino-6-deoxystarch sulfate were used as anticoagulants.

A modification of the Lee and White method was used ${ }^{18)}$. The anticoagulant activity assay was carried out as follows: a solution of sodium aminopolysaccharide sulfate in water $(0.1 \mathrm{ml})$ at a predetermined concentration in a glass test tube was warmed at $37^{\circ} \mathrm{C}$ in a water bath. Blood $(1 \mathrm{ml})$ was drawn from the artery of a dog by a syringe. The blood was added into the anticoagulant solution in the test tube and kept at $37^{\circ} \mathrm{C}$. The timer was started when blood was drawn by a syringe. The fluidity of the blood was checked at approximately every $30 \mathrm{sec}$ interval shown in Fig. 1. When the blood completely coagulated, the coagulation time was measured. This test was continuously done for each of sodium aminopolysaccharide sulfates as the anticoagulant.

Preparation of anticoagulant films ..... A pyrex test tube which contained a solution of

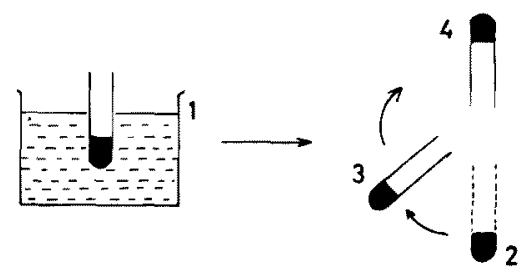

Fig. 1 Assay for whole blood-coagulation time by test tube method (Lee and White method).

sodium aminopolysaccharide sulfate $(2 \mathrm{mg})$ in $5 \%$ aqueous formalin ( $2-3$ drops) or an aqueous PVA ( $2 \mathrm{mg}$ in $0.1 \mathrm{ml}$ of water) solution was swirled on heating in an oil bath at $80^{\circ} \mathrm{C}$ and then further heated at $80^{\circ} \mathrm{C}$ for $1 \mathrm{hr}$ in a vacuum oven. Anticoagulant films were formed on an inner wall of the pyrex test tube. The change in fluidity of blood in the test tube was checked by Lee and White method as described above.

\section{REFERENCES}

1) M. Matsuda, M. Aoshima, N. Daitoh, K. Yamada, N. Tatsuta and Y. Kikasa, Blood and Vessels, 16, 219 (1978).

2) E. W. Davie, K. Fujikawa, K. Kurachi, and W. Kisiel, Advances in Enzymology, 48, 277 (1978).

3) J. G. Lemadam, S. Frye, Jr., and G. E. Phillips, Clin. Chem., 12, 263 (1966).

4) A. B. Foster and A. J. Huggard, Advances Carbohydr. Res., 10, 335 (1955).

5) L. H. Lam, J. E. Silbert, and R. D. Rosenberg, 
Biochem. Biophys. Res. Comm., 69, 570 (1976).

6) Z. Yoshizawa, Tanpakushitsu Kakusan Kooso, 14, 595 (1969).

7) D. Horton and E. K. Just, Carbohydr. Res., 29, 173 (1973).

8) R. L. Whistler and G. A. Towle, Arch. Biochem. Biophys., 138, 39 (1970).

9) D. Horton and E. K. Just, Carbohydr. Res., 30, 349 (1971).

10) M. L. Wolfrom and P. Y. Wang, ibid., 18, 23 (1971).

11) R. L. Whistler and M. Mosik, Arch. Biochem. Biophys., 142, 106 (1971).

12) T. Teshirogi, H. Yamamoto, M. Sakamoto, H. Tonami, Sen-i Gakkaishi, 36, T-560 (1980).
13) Y. Sakurai, Igaku Kikai Zairyo, 42 (12), 53 (1972).

14) Y. Sakurai, Kogyo Zairyo, 25 (1), 25 (1977).

15) K. Atsumi, Naika, 34 (4), 69 (1976).

16) H. Tanzawa, Kogyo Zairyo, 25 (7), 68 (1978).

17) S. Sasaki, Monbushoo Tokutee Kenkyu, 1978, p 113.

18) S. Hino, "Rinsyo Kensa Koza", 15, Ketsuekigaku, 1972, p 94.

19) T. Teshirogi, H. Yamamoto, M. Sakamoto, H. Tonami, Sen-i Gakkaishi, 34, T-510 (1978).

20) Idem., ibid., 35, T-525 (1979).

21) Idem, ibid., 36, T-501 (1980).

22) Idem., ibid., 35, T-479 (1979).

23) Y. Yamaura, "Igaku Jikkenkooza", 13, 1973, p45.

硫酸化アミノデオキシセルロースの抗血液凝固性

$\begin{array}{ll}\text { 山形大学工学部 } & \text { 手代木玩磨 } \\ \text { 東京工業大学工学部 } & \text { 草桶秀夫・坂本宗仙 } \\ \text { 日本女子大学家政学部 } & \text { 研波宏明 }\end{array}$

アミノデオキシセルロース硫酸化物のナトリウム塩水 溶液の抗血液凝固能をLee \& White法で挨討し, 著し い効果をもつととを見い出した。

さらに，選択的了ミ/デオキシ化セルロースからのナ
トリウム塩とホルマリンあるいはポリビニルアルコール 水溶液の混合物を熱好理し，内壁を薄膜でコーティング した試験管中では，血液は全く疑固しないことを見い出 した。 